\title{
Hjalmar Schacht e a economia alemã (1920-1950) ${ }^{1}$
}

\author{
Joaquim Miguel Couto ${ }^{2}$ \\ Gilberto Hackl ${ }^{3}$
}

\section{Resumo}

O objetivo deste artigo é expor as idéias econômicas de Hjalmar Schacht (1877-1970) e explicar suas medidas práticas para a resolução dos principais problemas enfrentados pela Alemanha na primeira metade do século XX. Schacht teve papel-chave no término da hiperinflação alemã na década de 1920, nas negociações das reparações de guerra (planos Dawes e Young), na superação da grande depressão dos anos 1930 (acabando com o desemprego e tornando a Alemanha, novamente, uma potência econômica) e, por fim, formulou um novo plano para superar a crise econômica vivida pelo seu país após o término da Segunda Guerra. Utilizou duas ilusões monetárias: a do Rentenmark, que ajudou a terminar com a inflação; e a do Saques Mefo, que financiou as obras públicas que extinguiriam o desemprego. Por seu sucesso na resolução de problemas econômicos, foi considerado um "bruxo" por muitos. Na verdade, Hjalmar Schacht conhecia apenas o funcionamento do sistema capitalista; as relações existentes entre as variáveis econômicas.

Palavras-chave: Schacht, Hjalmar; Inflação; Desemprego; Moeda; Alemanha.

\section{Abstract \\ Hialmar Schacht and the German economy (1920-1950)}

The aim of this article is to show Hjalmar Schacht's (1877-1970) economical ideas, as well as to explain his practical measures regarding the resolution of the main problems faced by Germany in the first half of XX century. It was concluded that Schacht had an important role in the extinction of German hyperinflation in the1920's decade, in the negotiations of the war reparations (Dawes and Young's plans), in overcoming the great depression of the1930s (putting an end to the unemployment and making Germany an economical potency once again) and, finally, formulating a new plan to overcome the economical crisis experienced by his country after the end of World War II. Two monetary illusions were used: Rentenmark's one that helped to finish with the inflation, and Saques Mefo's one that financed the public works which would extinguish the unemployment. Due to his achievements, he was considered as a 'wizard' by many people. Actually, Hjalmar Schacht just knew the operational working of things, and the existing relationships among the economical variables as well.

Key words: Schacht; Inflation; Unemployment; Coin; Germany.

JEL B31; E 31; E52; N14; N34.

\section{Introdução}

O dinheiro é uma coisa misteriosa. Possui certos enigmas e segredos. Por exemplo, ainda hoje, boa parte da população brasileira acredita, erroneamente, que

(1) Trabalho recebido em novembro de 2006 e aprovado em março de 2007.

(2) Professor do Departamento de Economia da Universidade Estadual de Maringá, Paraná, Brasil. E-mail: <miguelcouto@bol.com.br>.

(3) Bacharel em Ciências Econômicas pela Universidade Estadual de Maringá, Paraná, Brasil. E-mail: $<$ herrhackl@yahoo.de>. 
o dinheiro em circulação no país tem por base as reservas de ouro no Banco Central. Saber administrar a quantidade de dinheiro necessária ao bom funcionamento da economia é uma das grandes artes da sociedade moderna. A política monetária se reveste, assim, de uma grande importância, determinando, muitas vezes, o sucesso ou o fracasso das atividades econômicas. Hjalmar Schacht conhecia os segredos da moeda no sistema capitalista.

A maioria dos indivíduos passa pela vida sem grande influência sobre o destino de sua região, menos ainda de seu país; no entanto, existem algumas pessoas que exercem tamanha importância no destino da nação que as épocas da história são lembradas pela passagem desses homens.

Hjalmar Schacht é um deles. Coube-lhe influir no destino de seu país e na vida de milhões de alemães. Na sua época, todos o conheciam; hoje, porém, jovens professores alemães de economia chegam a desconhecer o seu nome.

Sob o comando de Schacht, a Alemanha conseguiu sair da hiperinflação dos anos 1920. Com suas idéias e liderança, retirou seu país da grande depressão dos anos 1930, acabando com o desemprego de cerca de $40 \%$ da força de trabalho, sem causar pressões inflacionárias. Tornou a Alemanha uma superpotência no final da mesma década, levando o presidente do país a ser eleito pela revista norteamericana Time o "homem do ano de 1938". O presidente era Adolf Hitler.

Por suas façanhas no campo da economia monetária, foi considerado por alguns como um bruxo, um feiticeiro. Na verdade, era um homem que sabia como funcionava o mundo econômico. Entendia a relação existente entre as muitas variáveis do sistema capitalista, e desse modo podia combiná-las para o melhor resultado.

Destarte, o objetivo deste artigo é compreender as idéias econômicas de Hjalmar Schacht e explicar suas medidas práticas na resolução dos principais problemas enfrentados pela Alemanha na primeira metade do século XX.

\section{A formação e os primeiros empregos ${ }^{4}$}

Horace Greeley Hjalmar Schacht nasceu na cidade de Tingleff, em Nordschleswig (atual região da Jutlândia, Dinamarca), no dia 22 de janeiro de 1877. Estudou na Johanneum, escola de elite alemã, situada em Hamburgo, tendo seu pai custeado seus estudos com grande esforço, já que não era um homem rico. Concluiu os estudos na Johanneum em 1895.

Nesse mesmo ano, ingressou na Universidade de Kiel, para estudar medicina, mas não completou o curso. Nos quatro anos e meio em que freqüentou

(4) Esta seção está baseada na autobiografia de Schacht, intitulada "Setenta e seis anos de minha vida" (1999). 
as cadeiras escolares superiores estudou em cinco universidades diferentes: Kiel, Berlim, Munique, Leipzig e Paris. Cursou diversas disciplinas: medicina, filologia germânica, história da literatura, jornalismo, economia, retórica, francês e sociologia. Não obstante, a ciência que mais estudou foi a economia. Nessa área escreveu sua tese de doutoramento, com o tema "O conteúdo teórico do mercantilismo inglês". No dia do exame final, foi inquirido por um professor de filosofia, e por isso recebeu o título de "Doutor em Filosofia" em vez de "Doutor em Economia".

Começou a trabalhar no Instituto de Economia de Gustav Von Schmoller e a escrever artigos tanto para o Anuário Schmoller como para o Anuário Prussiano. Seu primeiro artigo no Anuário Prussiano, de 1901, tratava do protecionismo. Mostrava-se um liberal, contra a intervenção do Estado na economia e a favor do livre-comércio. No Instituto de Economia, escreveu artigos defendendo uma política de comércio exterior que privilegiasse a exportação de bens industriais em vez de matérias-primas e produtos semi-industrializados. Sua preocupação já era o desemprego: "É hora de criar empregos para os milhões de alemães que povoam o solo alemão e nascem do seio da mãe-pátria. Essas massas populacionais não podem mais ser acomodadas na produção de grãos ou na fabricação de produtos semi-industrializados, mas sim, por um lado, em pequenas empresas de agropecuária intensiva e, por outro lado, na indústria de produtos industrializados" (Schacht, 1999, p. 149-150).

Seu primeiro emprego efetivo foi o de assistente na Sociedade de Contratos Comerciais, uma espécie de associação comercial. Foi o único emprego a que Schacht teve que se candidatar, pois para todos os outros seria convidado. No mesmo ano de seu casamento (1903), Schacht deixou a Sociedade de Contratos Comerciais e aceitou o convite para trabalhar no terceiro maior banco da Alemanha, o Dresdner Bank, como relações-públicas da instituição. Ao mesmo tempo, percorreu e conheceu profundamente todos os setores da instituição.

Em 1905, acompanhou um membro da presidência do banco a uma viagem até Nova York, em razão de um contrato comercial com o banco Morgan \& Co. Conheceu o banqueiro John P. Morgan e, em Washington, visitou o presidente Theodore Roosevelt, na Casa Branca.

Aos 32 anos, em 1909, tornou-se diretor titular do Dresdner Bank, dirigindo a administração das filiais e o seu departamento econômico. Continuava a escrever para o Anuário Prussiano e o Anuário Schmoller. Segundo Schacht, um banqueiro não precisava ser bom de matemática: “(...) o importante é o domínio de outras artes: psicologia, por exemplo, conhecimento de economia, bom senso, a capacidade de decisão, mas sobretudo conhecimento sobre crédito" (1999, p. 88). No final de 1915, por certas questões que o incomodavam, Schacht pediu 
Miguel Couto

demissão do Dresdner Bank, após treze anos de trabalho. Já era um homem relativamente rico. Aceitou um novo convite, desta vez para trabalhar na direção do Nationalbank.

Com a derrota da Alemanha na Primeira Guerra, a revolução interna derrubou o imperador Guilherme II e implantou a República de Weimar, em novembro de 1918. A confusão política em que se encontrava a Alemanha nessa época levou Schacht a organizar, junto com alguns amigos, um novo partido político: Partido Democrático Alemão (DPP), em novembro de 1918. Nas eleições de janeiro de 1919, o DDP obteve 74 lugares na Assembléia Nacional, evitando que o Partido Social Democrata governasse sozinho e levasse a Alemanha para o socialismo. Schacht não se candidatou a nenhum cargo. Continuava a trabalhar no Nationalbank.

Em 1921, o Nationalbank fundiu-se ao Darmstadter Bank, originando um novo banco, o Danat-Bank. Schacht foi contra a fusão. Vencido, continuou trabalhando na instituição, mas sem grande motivação. Preocupava-se, na época, com a política monetária e as reparações de guerra que a Alemanha deveria pagar aos países Aliados (França e Inglaterra, principalmente). ${ }^{5}$

\section{Tratado de Versalhes e as reparações de guerra}

As forças aliadas que venceram a Primeira Guerra Mundial reuniram-se na Conferência de Paz de 1919, em Versalhes (França), para tratar das estratégias que garantissem a paz no continente europeu. Estavam presentes o primeiro-ministro da França, Georges Clemenceau, o presidente dos Estados Unidos, Woodrow Wilson, e o primeiro-ministro inglês, David Lloyd George. Com o passar dos dias, a Conferência foi se revelando apenas uma reunião para estipular quanto a Alemanha deveria pagar pelas perdas decorrentes da Grande Guerra, relegando a um plano secundário a garantia da paz.

O resultado da Conferência de Paris ficou exposto no Tratado de Versalhes, assinado pelos aliados e pelos representantes alemães em 28 de junho de 1919. O tratado causava sérios danos econômicos à Alemanha e, pode-se dizer, sem receio, que o seu resultado, altamente desfavorável e humilhante para a Alemanha, abriria o caminho para a Segunda Guerra.

Autores como Fest (1976), Schacht (1931) e Reis (2001) afirmam que, dentre os 440 artigos redigidos no Tratado de Versalhes, os que trouxeram maiores conseqüências à economia alemã foram: a) o pagamento de reparações de guerra aos países vencedores, cujo valor seria posteriormente definido; b) a destruição de

(5) "Quanto menos prazer me dava o trabalho no Danat, tanto mais me ocupava das questões econômicas públicas. Além dos problemas de política monetária, preocupava-me sobretudo com a questão das reparações de guerra" (Schacht, 1999, p. 230). 
todos os armamentos e equipamentos de guerra alemães; c) a proibição de edificar qualquer espécie de construção militar na região das margens do rio Reno; d) a perda da região mineradora do Sarre para a França, como compensação aos prejuízos causados durante o conflito; e) a entrega de oficiais alemães nominalmente escolhidos para julgamento; f) a imposição à Alemanha de toda a responsabilidade moral pela guerra; g) a perda dos territórios do Togo (para a GrãBretanha e a França), de Camarões (para a França), da Tanzânia e Namíbia (para a Grã-Bretanha), de Ruanda-Burundi (para a Bélgica), das Ilhas Marianas e Ilhas Carolinas (para o Japão), do Arquipélago de Bismarck (para a Austrália), além da anexação da região da Alsácia-Lorena pela França e da anexação das regiões germânicas da Pomerância, Prússia Ocidental e Alta Silésia pela Polônia. A perda das colônias e de algumas regiões européias reduziu o território do império alemão de $2.915 .069 \mathrm{~km}^{2}$ para apenas $540.000 \mathrm{~km}^{2}$ (Reis, 2001).

John Maynard Keynes, eminente economista inglês, que fazia parte da delegação britânica na Conferência de Paz, inconformado com os rumos das negociações impostas pelos aliados, abandonou a conferência antes de seu término. Como repúdio aos resultados da conferência, publicou, no final de 1919, o livro "Conseqüências econômicas da paz", de enorme sucesso de vendas. Nele, Keynes considerava diversas cláusulas do Tratado abusivas e lesivas aos interesses alemães, indo desde o tratamento dado às propriedades privadas de cidadãos alemães em colônias africanas e nas regiões perdidas até as apropriações e controles exercidos sobre a rede ferroviária e o volume de carvão entregue à França. Em vários pontos do livro, Keynes (2002) deixava entender que as cláusulas do Tratado não levariam à paz, mas sim, a uma nova guerra.

A opinião de Keynes não era isolada. Em novembro de 1919, o senado dos Estados Unidos rejeitou o Tratado de Versalhes por julgá-lo indecente. Winston Churchill, na época ministro da Guerra e do Ar do governo britânico, classificou como malévolas e inúteis as cláusulas econômicas do Tratado, de forma que elas serviam para expressar toda a raiva dos vencedores e a incapacidade destes em compreender que nenhuma nação derrotada pode jamais pagar tributos em escala comparável ao custo da guerra (Reis, 2001).

Quanto às reparações de guerra que a Alemanha deveria pagar aos aliados, os debates travados na Conferência levaram ao adiamento da definição de seu montante. Keynes (2002) calculou a seguinte cifra: 8 bilhões de libras esterlinas, sendo 3 bilhões pelos danos causados pela guerra e 5 bilhões em pensões e indenizações. ${ }^{6}$ No entanto, no Ultimato de Londres, apresentado à Alemanha em maio de 1921, a cifra foi estipulada em 24 bilhões de libras esterlinas, que

(6) Sobre as reparações de guerra que levaram a economia alemã à "beira do abismo", Schacht cita o mérito de Keynes em ver no Tratado de Versalhes sua "inaplicabilidade econômica" (Schacht, 1950, p. 44). 
consumiriam anualmente $80 \%$ das exportações alemãs. Em seu livro sobre as reparações de guerra, Schacht (1931) considerava o montante impossível de ser pago, dada a situação econômica vigente. ${ }^{7}$

Nessa época, Schacht fazia parte da diretoria do Danat-Bank, e, apesar de não pertencer à comissão governamental alemã que negociava as cifras das reparações, já demonstrava sua posição de questionamento da exeqüibilidade econômica das reparações. Em 1921, numa visita a Paris, encontrou-se com alguns membros do governo francês, inclusive com o ministro das Finanças, Charles de Lasteurie, em que ressaltou a impossibilidade de a Alemanha pagar os valores impostos pelos Aliados (Schacht, 1931). Em maio de 1923, discutiu em Londres, perante uma associação industrial inglesa, as dificuldades encontradas pela Alemanha para pagar as fantásticas quantias das reparações, que favoreceram o aumento da inflação. Sobre esse encontro, escreveu Schacht (1999, p. 230): "Embora tenha me defrontado ali com uma antipatia geral contra a Alemanha, as conversas, porém, tiveram caráter bastante objetivo e também gentil. A todos os participantes parecia desejável uma retomada dos negócios entre Alemanha e Inglaterra. Além de algumas questões políticas (...) o foco da discussão centrou-se nas reparações. O governo alemão considerava viável uma quantia de no máximo 20 bilhões de marcos". Os ingleses julgaram a quantia demasiadamente baixa, dado que o Ultimato de Londres estabelecia o valor de 120 bilhões de marcosouro. Como resposta, o economista alemão disse que era a oferta mais honesta que poderia se oferecer, devido ao cenário atual da economia alemã. Julgava Schacht que esta quantia era possível pagar, sem falsas promessas e comprometimento futuro do país. Nesse mesmo dia, Schacht encontrou-se com o ex-ministro das finanças inglês, o banqueiro Reginald Mckenna, que considerou que mesmo os 20 bilhões oferecidos pela Alemanha ainda eram um valor muito alto (Schacht, 1999, p. 231-232).

Para Schacht (1931, 1999), o grande problema era que a moeda alemã só tinha aceitação na própria Alemanha; assim, o pagamento das reparações teria que ser feito somente em ouro ou mercadorias. Para tanto, os países aliados teriam que aumentar suas importações da Alemanha, o que significaria uma forte concorrência com as outras nações européias.

\section{A hiperinflação e a estabilização do marco alemão}

No mesmo período em que a Alemanha era obrigada a pagar uma quantia enorme em reparações de guerra, o país iria passar pelo terror da hiperinflação.

(7) Na sua autobiografia, publicada originalmente em 1953, Schacht (1999, p. 230) escreveu: "Hoje é unânime a idéia de que as reparações exigidas na época foram um absurdo econômico. Mas naquele tempo os políticos não tinham a menor idéia de como tais reparações poderiam ser pagas e quais seriam as conseqüências econômicas". 
Tratou-se de um dos maiores fenômenos monetários da história econômica mundial (Tabela 1).

Tabela 1

Taxa mensal de inflação na Alemanha (1919-1924)

\begin{tabular}{l|r|r|r|r|r|r}
\hline Mês & 1919 & 1920 & 1921 & 1922 & 1923 & 1924 \\
\hline Janeiro & 6,94 & 56,41 & $-0,07$ & 5,10 & 88,68 & $-7,01$ \\
\hline Fevereiro & 3,05 & 34,16 & $-4,38$ & 11,95 & 100,68 & $-0,98$ \\
\hline Março & 1,48 & 1,43 & $-2,76$ & 32,42 & $-12,48$ & 3,87 \\
\hline Abril & 4,38 & $-8,31$ & 0,90 & 16,97 & 6,63 & 2,80 \\
\hline Maio & 3,85 & $-3,77$ & $-1,36$ & 1,62 & 56,75 & $-1,28$ \\
\hline Junho & 3,70 & $-8,36$ & 4,43 & 8,86 & 137,27 & $-5,36$ \\
\hline Julho & 10,06 & $-1,09$ & 4,54 & 43,09 & 285,80 & $-0,78$ \\
\hline Agosto & 24,49 & 60,70 & 34,24 & 90,87 & 1162,31 & 4,35 \\
\hline Setembro & 16,82 & 3,31 & 7,82 & 49,48 & 2431,67 & $-5,83$ \\
\hline Outubro & 14,00 & $-2,14$ & 19,01 & 97,21 & 29607,11 & 3,14 \\
\hline Novembro & 0,64 & 2,93 & 38,86 & 103,89 & 10121,13 & $-1,53$ \\
\hline Dezembro & 18,44 & $-4,57$ & 2,08 & 27,82 & 73,85 & 1,55 \\
\hline
\end{tabular}

Fonte: Visconti (1987, p. 8).

Nos primeiros meses de 1919, até a assinatura do Tratado de Versalhes, em junho de 1919, o movimento inflacionário permaneceu num patamar baixo, sendo acarretado, principalmente, pelo aumento dos preços dos produtos importados, devido às desvalorizações do marco alemão em relação ao dólar norte-americano. Entre julho de 1919 e fevereiro de 1920, temos uma subida da taxa de inflação, causada novamente pela rápida valorização do dólar (em razão dos compromissos acordados no Tratado de Versalhes). A partir de março de 1920, entramos num período de relativa estabilidade, inclusive com períodos de deflação. ${ }^{8}$ Porém, a inflação voltou com força a partir de agosto de 1921, permanecendo alta durante todo o ano de 1922. Dois acontecimentos motivaram sua volta: o Ultimato de Londres (maio de 1921), que impôs à Alemanha o pagamento de 1 bilhão de marcos-ouro em indenização; e a transferência da região da Alta Silésia para a Polônia (outubro de 1921), que gerou pânico na população e corrida ao dólar (desvalorizando o marco).

Com o tempo, os preços passaram a mostrar uma tendência de adaptação à taxa do dólar. Assim, as flutuações no nível de preços ficavam intimamente ligadas à flutuação cambial, sendo freqüente os preços internos se ajustarem automaticamente à cotação do dólar. Com isso, a moeda nacional perdia sua função de unidade de conta e de reserva de valor, apesar de os pagamentos serem efetuados em marcos, o que caracterizava a moeda apenas como meio de pagamento (Franco, 1999).

(8) Bresciani-Turroni (1989) afirma que até 1921 a inflação alemã era decorrente dos seguintes fatores: a) emissão de moeda para cobrir o déficit orçamentário do governo; b) escassez de bens (ocasionado pela guerra); c) elevação dos preços dos bens importados (causado pela alta do dólar); d) reparações de guerra (decorrentes do Tratado de Versalhes). 
Não obstante, a inflação desse período foi benéfica tanto para as empresas como para a classe trabalhadora (sem considerar a perda de seu poder aquisitivo). Por uma dinâmica de certo modo estranha, a economia alemã crescia com a inflação, absorvendo mão-de-obra. Segundo Bresciani-Turroni (1989), a inflação e a inexistência da indexação forçavam as famílias a gastar suas rendas tão logo as recebiam. As empresas, por sua vez, investiam imediatamente seus lucros, aumentando a produção industrial rapidamente. O elevado consumo e o alto investimento foram os responsáveis pelo baixo desemprego nessa época. Em meados de 1922, o desemprego havia desaparecido na Alemanha.

Por outro lado, havia setores que estavam se beneficiando em demasia com a inflação, em detrimento dos demais. O setor agropecuário conseguia quitar suas dívidas com moeda desvalorizada e o setor industrial passou a emitir suas próprias moedas. Schacht via essa situação com grande repulsa, o que reforçaria seu desejo de participar ativamente no processo de estabilização da moeda:

Como em todas as questões econômicas, especialmente em questão de dinheiro, as pessoas instruídas entendem o processo de desvalorização mais rapidamente do que a grande massa inexperiente. Quem percebeu a inflação a tempo pôde proteger-se contra as perdas do papel-moeda, comprando o mais rapidamente possível bens quaisquer, que, ao contrário do papel-moeda em desvalorização, mantivessem seu valor como casas, terras, produtos, matérias-primas e outras mercadorias. A fuga para os bens possibilitou não apenas às pessoas abastadas, mas em particular também àqueles negociantes inescrupulosos, salvarem suas fortunas e possivelmente aumentá-las. A conseqüência dessa luta para enriquecer e manter a fortuna, explorando a ignorância da grande massa, foi o envenenamento moral de todos os negócios. A poupança em dinheiro deixou de existir (...) Inquietação imensa e amargura crescente tomavam conta dos operários, dos funcionários e aposentados, que não podiam mais pagar o sustento diário (...) Diversos empresários passaram a pagar seus trabalhadores com mantimentos (Schacht, 1999, p. 221).

Mas o pior em relação à inflação ainda estava por vir. A suspensão dos pagamentos das reparações de guerra pela Alemanha (em agosto de 1922) causou uma desconfiança geral da população em relação à administração das finanças públicas. Segundo Bresciani-Turroni (1989), foi a partir desse episódio que a Alemanha efetivamente ingressou num processo de hiperinflação.

A diferença entre inflação e hiperinflação é vista por muitos autores apenas em relação às taxas de inflação. Segundo Zini Júnior (1993, p. 2), um processo hiperinflacionário é caracterizado quando os preços sobem acima de $1.000 \%$ ao ano, ou acima de $22 \%$ ao mês. Nas palavras do autor, "as hiperinflações são processos de crescimento descontrolado dos preços e perda rápida do valor da moeda" (Ibid.). Já para Franco (1995), é comum que se aceite, na falta de um critério melhor, que uma hiperinflação começa quando ultrapassa $50 \%$ mensais e termina quando esses níveis deixam de ser alcançados durante um 
ano. No entanto, podemos acrescentar outra característica que diferencia os dois processos: as funções da moeda. Num processo de inflação, a moeda perde suas funções de reserva de valor e meio de conta, mas ainda é aceita como meio de pagamento. Já num processo de hiperinflação, a função de meio de pagamento da moeda também é perdida, pois os agentes passam a adotar uma outra moeda para essa finalidade. Isso ocorreu na Alemanha.

A suspensão dos pagamentos das reparações de guerra levou a França e a Bélgica a ocuparem a rica região do vale do rio Ruhr, em janeiro de 1923. A Alemanha, visando evitar que as empresas e trabalhadores do Ruhr produzissem carvão e aço para os invasores, passou a pagar as empresas para não produzirem. Para financiar essa "resistência passiva", o governo alemão recorreu à emissão de papel-moeda. A grande soma gasta na resistência passiva fez com que a Alemanha perdesse completamente o controle das finanças públicas. Para Zini Júnior (1993, p. 13), “(...) este foi o fator final para deflagrar a hiperinflação aberta em 1923”.

Observando a Tabela 1, verificamos que o período mais dramático da hiperinflação foram os meses de agosto, setembro, outubro e novembro de 1923. A taxa de inflação de outubro de 1923 foi de $29.607 \% .{ }^{9}$ Os preços eram cotados em algum tipo de indexador, na maioria das vezes em moeda estrangeira. Os agentes domésticos investiam suas sobras também em moeda estrangeira, dificultando a tributação interna. A dolarização dos preços atingiu toda a população, tornando-se um "fenômeno de massas", nas palavras de BrescianiTurroni (1989). O cenário era tão grave que o Reichsbank (banco central alemão) não conseguia atender à demanda pela impressão de novas notas:

Logo chegou o dia em que era necessária uma nota de 1 bilhão de marcos para comprar uma passagem de bonde. Inúmeras cidades e firmas passaram a imprimir seu próprio 'dinheiro de emergência' e com ele pagar despesas. O Reichsbank não pôde recusar-se a aceitar aquele dinheiro em seus caixas e a tratá-lo como de igual valor que as próprias cédulas. Tornou-se impossível controlar o dinheiro de emergência emitido. Toda a circulação de meios de pagamento se tornou um caos (Schacht, 1999, p. 222).

A disseminação de outras moedas estrangeiras mais estáveis que a moeda alemã fez com que o marco perdesse, inclusive, a sua função de meio de pagamento. Em novembro de 1923, o estoque de marcos em circulação era irrisório (Franco, 1995).

A hiperinflação desorganizou a vida econômica: as vendas caíram e a produção cessou, causando o desemprego. Se em setembro de 1923 havia cerca de 250 mil desempregados, em 15 de novembro eram 1,485 milhão (BrescianiTurroni, 1989).

(9) Nas palavras de Galbraith (1994, p. 27), “(...) os preços subiam dia a dia, em pouco tempo, hora a hora. A única proteção não era ter depósitos bancários, mas notas de papel que podiam ser gastas rapidamente”. 
Surpreendia a todos que, nesse clima de insolvência monetária, o Reichsbank se mantinha passivo. Na época, a presidência do Reichsbank era vitalícia. O cargo era ocupado por Rudolf Von Havenstein, que era a favor de uma política de tolerância com a inflação e se negava a qualquer reforma monetária enquanto as negociações em relação às reparações de guerra não se definissem. Schacht escreveu sobre esse momento:

No verão de 1923, a miséria da inflação alemã atingiu seu auge. Cinco anos após o término da Primeira Guerra Mundial, a Alemanha se contorcia sob uma febre que ameaçava consumir suas últimas forças. Por toda a parte na Saxônia, Turíngia e Baviera inflamavam-se tumultos. No sul, Hitler fazia agitações. O governo comunista/social-democrata de Zeigner, na Saxônia, deu rédea solta ao terror vermelho. Em Hamburgo aconteceram lutas furiosas nas ruas durante dias, tendo sido mortos quinze policiais e 65 civis. 'O país arrebentava em todas as suas fendas', escreveu um observador. A inflação levava todos ao desespero. O perigo de uma revolução comunista era ameaçador (Schacht, 1999, p. 233)

A grave situação econômica por que a Alemanha passava em junho de 1923 levou tanto o governo como a sociedade a refletirem sobre a necessidade urgente de uma reforma monetária, independentemente do andamento das negociações das reparações de guerra (Franco, 1995). No dia 12 de novembro de 1923, no mês mais agressivo da inflação alemã, o ministro das Finanças, Hans Luther, chamou Schacht a seu gabinete para uma conversa sobre a reforma monetária. Foi oferecido a Schacht o cargo de Secretário da Moeda do Reich, o qual já havia sido recusado por duas outras pessoas. Schacht aceitou o cargo, tomando posse no dia seguinte. Pediu, então, demissão do Danat-Bank. Tinha 46 anos de idade (Schacht, 1978, 1999). ${ }^{10}$

Depois de calorosos debates no parlamento alemão entre a esquerda e a direita, chegou-se à conclusão de que o plano teria a introdução de uma nova moeda chamada de rentenmark, idéia formulada originalmente pelo professor e deputado Karl Helfferich (com o nome de roggenmark, ou seja, marco-centeio). A nova moeda teria como garantia a hipoteca dos bens imobiliários alemães, de forma que o rentenmark pudesse ser trocado por uma cédula hipotecária de igual

(10) Sobre esse momento em sua vida, escreveu Schacht (1999, p. 237): "Até aquele dia 12 de novembro, no qual destruí as pontes através de mim, havia sido um homem feliz em minha vida particular. Tinha minha família, meu círculo de amigos, meu meio de subsistência, um lar aconchegante, podia compartilhar minhas preocupações de negócios com colegas de iguais responsabilidades - em resumo, se não estivesse animado pelo impulso ardente de ajudar meu povo, teria continuado minha vida provavelmente de forma relativamente tranqüila e agradável. Contudo, a preocupação com o bem-estar de meu povo nunca me abandonou. Desejava ajudar a economia alemã com minha atividade bancária e não considerava minha profissão um negócio lucrativo. Via o perigo de a Alemanha sucumbir ao comunismo e considerava minha obrigação não me esquivar de uma tarefa que esperava poder cumprir". O bisavô materno de Schacht, o dinamarquês Christian Von Eggers, implantou uma reforma monetária na Dinamarca, no final do século XVIII. Em relação a esse assunto, Schacht comentou: “A estabilização de moedas, portanto, está por assim dizer no sangue!" (1999, p. 70). 
valor a qualquer momento. ${ }^{11}$ A emissão seria efetuada pelo Rentenbank, que seria, em teoria, um banco de emissão independente do Reichsbank, cabendo, porém, a este último o gerenciamento pela distribuição da moeda, assim como a realização de empréstimos em rentenmark. No dia 15 de novembro de 1923, foi instituída oficialmente a reforma monetária no país com a introdução do rentenmark, sob o comando de Schacht. Como num passe de mágica, a hiperinflação terminou. O sucesso não esperado da reforma foi considerado milagroso: "o milagre do rentenmark". ${ }^{12}$

A impressão das notas de rentenmark levou cerca de um mês para ficar pronta. Assim, no início, o rentenmark funcionou apenas como um indexador. Para Schacht, a aceitação da nova moeda pelo povo foi extraordinária. A demanda foi muito alta, sendo que filas se formavam para a aquisição do rentenmark, principalmente pelo fato de sua indexação ao dólar (Franco, 1995; Schacht, 1978, 1999). ${ }^{13}$

O segundo passo para o sucesso da estabilização foi o congelamento da taxa de câmbio, em 20 de novembro de 1923, dia histórico da estabilização monetária alemã. Nesse dia, 1 dólar alcançou a cotação de 4,2 trilhões de marcos, e 1 rentenmark foi cotado a 1 trilhão de marcos. Dessa forma, 1 rentenmark seria igual a 4,2 dólares.

Nesse mesmo dia morria o presidente do Reichsbank. Para o seu cargo foram sugeridos dois nomes: Schacht, que estava cuidando do processo de estabilização, e o professor Karl Helfferich, precursor da idéia do rentenmark. A diretoria do Reichsbank era favorável ao deputado Helfferich, porém o escolhido foi Schacht, como forma de dar continuidade às mudanças em prol de uma moeda estável. Em 22 de dezembro, Schacht foi nomeado presidente vitalício do Reichsbank pelo presidente alemão Friedrich Ebert.

(11) Para Bresciani-Turroni (1989), as garantias do rentenmark eram simplesmente fictícias: o rentenmark era um papel sem nenhum lastro. Já Webb (1989), qualificou o experimento de "fábula": o rentenmark não era conversível nem lastreado em ouro. Gustavo Franco elaborou um resumo do pensamento de alguns economistas sobre o rentenmark: Sargent dizia que "embora tenha se atribuído um extraordinário efeito psicológico a essa mudança de unidade, é difícil atribuir qualquer efeito substancial ao que nada mais era que uma medida cosmética"; Angell referiu-se ao rentenmark como um truque de expectativas; Stolper definia como um artifício psicológico; e Graham como "nada mais que um novo tipo de papel inconversível" (Citados por Franco, 1999, p. 33).

(12) Sobre esse assunto, escreveu Galbraith (1989, p. 440): "No final de 1923, em um dos episódios mais notáveis na história do dinheiro, a inflação alemã foi eliminada (...) Foi mais uma razão para as pessoas atribuírem poderes mágicos ao dinheiro".

(13) Para compreender melhor o funcionamento do rentenmark, convém fazer um paralelo entre o rentenmark e a URV (unidade real de valor), que vigorou durante quatro meses no Brasil, antes da implantação da nova moeda em julho de 1994. Tanto a URV como o rentenmark serviram como indexador e para o realinhamento dos preços até a introdução da nova moeda. A URV foi substituída pelo Real e o rentenmark pelo reichsmark. 
Faltava dar um último passo em direção à estabilização e, segundo Schacht (1978), o mais difícil: combater o dinheiro de emergência, emitido pelo setor público e pelas empresas privadas, os "Notgeld". Era uma situação em que o banco central não era o único responsável pela emissão de papel-moeda, de forma que caracterizava uma situação que Schacht (1999, p. 241) denominou como "cada um com seu próprio Reichsbank". O Reichsbank, sob o comando de Schacht, declarou que o dinheiro de emergência não seria mais aceito pelo banco central, tornando inútil sua emissão. Logo foi sentida a indignação dos empresários, que haviam tirado proveito da emissão de sua própria moeda. A reação foi maior na região industrial da Renânia-Vestfália. Essa região marcou uma reunião de emergência para o dia 25 de novembro de 1923 com os representantes do Reichsbank. Depois de escutar por três horas a reivindicação dos empresários industriais, que queriam a volta da aceitação do dinheiro de emergência, Schacht discursou aos empresários:

Admito que a interrupção do dinheiro de emergência lhes causa transtornos, embaraços e dificuldades. Porém nenhum de seus argumentos tem importância em face das necessidades de tornar a moeda alemã novamente estável (...) A grande massa do povo alemão trabalhador tem de recuperar, com uma moeda estável, um chão firme sob os pés. Por isso concluo a discussão de hoje com a declaração irrevogável de que o Reichsbank permanecerá em sua decisão de rejeitar o dinheiro de emergência. Os senhores terão que se acostumar de novo a dirigir suas casas com cifras monetárias estáveis (Schacht, 1999, p. 242).

Quando surgiu a idéia do rentenmark, Schacht não foi muito favorável. Para ele, somente o rentenmark não conseguiria estabilizar os preços, sem congelar a taxa de câmbio e proibir o dinheiro de emergência. Sobre o assunto, já no final da Segunda Guerra, escreveu:

Quando a Alemanha intentou em 1923 frear por seus próprios meios a inflação, mediante a introdução de uma nova moeda, isto não se verificou mediante o Roggenmark [marco-centeio] proposto por Helfferich [dirigente do partido nacional alemão], porque o centeio, com suas oscilações de preços a curto prazo, resultava impossível para ser contemplado como base monetária e, quando em lugar do Roggenmark se propôs o Rentenmark [marco-renda], que tinha sua cobertura nos bens raízes, não terminou ali essa medida, senão que se agregou ao Rentenmark um valor ouro, constituído pelo mesmo valor do ouro que tinha o Reichsmark antes da inflação. Já é tempo de que desapareça de uma vez por todas a lenda do Rentenmark. O Rentenmark era uma construção impossível desde o ponto de vista monetário. Nunca tinha constituído tampouco um meio de pagamento total (Schacht, 1950, p. 33).

Schacht (1999, p. 220) explicava que a palavra "moeda" era derivada de "wabren", que significava "durar". Assim, a principal tarefa da política monetária era manter constante o valor do papel-moeda, permanecendo o seu poder aquisitivo ao longo do tempo (Schacht, 1978). 
Outro segredo do sucesso do rentenmark, segundo Franco (1995), foram a emissão limitada da nova moeda e o nível de reservas internacionais existentes em novembro de 1923, que garantia a cobertura de cerca de $70 \%$ da demanda por moeda estimada. Ainda segundo Franco (1995), outro importante fator para a estabilização foi a reforma fiscal da economia, que resultou no saneamento do déficit público.

Em 30 de agosto de 1924, foi promulgada a lei que introduzia o reichsmark como moeda oficial alemã a partir de 11 de outubro de 1924. Sua relação de paridade seria de 1 reichsmark para cada 1 rentenmark. O processo de substituição do rentenmark pelo reichsmark se deu de forma lenta, tendo sido fixado um limite máximo de dez anos para a retirada completa do rentenmark. Até 23 de agosto de 1926, o reichsmark manteve a paridade cambial como forma de garantir a equivalência com o dólar. A partir dessa data, esse sistema de âncora cambial foi abandonado e a taxa cambial passou a flutuar de acordo com as condições de mercado (Bresciani-Turroni, 1989).

Esse período da história alemã ficou conhecido pela população como a "Era da Inflação" (1920-1924). Schacht, escrevendo trinta anos depois, assim caracterizou esse período sombrio de seu país:

'Era da inflação' é, para todos os que ainda se lembram: bloqueio da entrada de alimentos no país, entrega de bens a potências estrangeiras, inexistência de direitos políticos, revolução social, enriquecimento repentino de figuras obscuras. Perda substancial das classes até então abastadas, empobrecimento das pequena, média e alta burguesias. Corrupção entre políticos e funcionários públicos, negociatas políticas entre os partidos, as Forças Armadas e os ministérios. Mortalidade infantil crescente, criminalidade crescente, jovens deformados por causa do raquitismo, morte prematura dos idosos. Tudo isso e muito mais está contido nas palavras 'era da inflação' (Schacht, 1999, p. 219).

\section{Golddiskontbank, Plano Dawes e Plano Young}

O passo seguinte de Schacht foi criar um banco de desenvolvimento para a Alemanha, que pudesse emprestar recursos visando à produção industrial, principalmente para a região industrial da Renânia-Vestfália, e com isso reativar a economia alemã. Para tanto, precisava de um empréstimo em moeda estrangeira. Assim, viajou até Londres para conversar com o presidente do Banco da Inglaterra (o banco central inglês). Chegou à capital inglesa no dia 31 de dezembro de 1923, sendo recebido por Montagu Norman, presidente do Banco da Inglaterra, na estação de Londres. As conversas tiveram início na manhã do Ano Novo de 1924. Schacht explicou da seguinte forma suas idéias a Norman:

Tenho a intenção de criar, ao lado do Reichsbank, um segundo banco de emissão, baseado totalmente no ouro. Esse banco abrirá crédito apenas contra títulos e socorrerá preferivelmente aquelas indústrias alemãs que possam retomar as 
exportações. Vou chamá-lo de Golddiskontbank (...) Imagino a criação do banco com um capital de 200 milhões de marcos. O capital deve ser conseguido em moeda estrangeira, digamos, em libra esterlina. Acredito que me será possível arranjar a metade do capital em moeda estrangeira dentro da Alemanha. Gostaria de solicitar a outra metade do banco da Inglaterra (Schacht, 1999, p. 253).

Norman concordou com a idéia de Schacht sobre o novo banco e aprovou o empréstimo, equivalente a 100 milhões de marcos em moeda estrangeira. Os juros cobrados seriam de $5 \%$ ao ano, metade dos juros internos cobrados na Alemanha. ${ }^{14}$ Os outros 100 milhões de marcos foram facilmente conseguidos dentro da própria Alemanha. O Golddiskontbank foi oficialmente criado em 13 de março de 1924, e sua direção estava nas mãos do Reichsbank: "Até a derrota no ano de 1945, o banco contribuiria com sucesso, como um instrumento do Reichsbank, para o apoio da moeda e para o fomento da exportação alemã" (Ibid., p. 262). ${ }^{15}$

Não obstante, a estabilidade da moeda ainda não estava concretizada. Schacht sabia que a estabilidade duradoura dependia de um acordo razoável sobre as reparações de guerra. Negociações governamentais resultaram na convocação de uma conferência para tratar do assunto. A Conferência Dawes se realizou em Paris (janeiro de 1924), tendo como presidente o general norte-americano Charles Dawes. No dia 23 de janeiro, Schacht prestou esclarecimentos aos membros da Conferência sobre a situação econômica da Alemanha. Os principais problemas eram o fornecimento forçado de mercadorias ao exterior, a luta na região ocupada do Ruhr e a inflação.

Enquanto a Conferência se desenvolvia em Paris, Schacht retornou à Alemanha. O rentenmark estava passando por um processo especulativo, e seu valor já mostrava um deságio de cerca de $15 \%$ em relação ao dólar. Especuladores alemães estavam vendendo rentenmark no exterior contra moedas estrangeiras. Para acabar com a especulação, Schacht suspendeu toda a concessão de crédito do Reichsbank, em 5 de abril de 1924: "Quando acaba a confiança em uma moeda, nem a mais alta das taxas de desconto ajuda a assustar os especuladores (...) Não se elimina, portanto, a especulação cambial por meio do desconto, mas pelo crédito. Decidimos bloquear totalmente o crédito cambial do Reichsbank para a economia" (Ibid., p. 268). A medida gerou uma revolta contra o Reichsbank, e Schacht chegou a ser chamado de "carrasco da economia alemã". No entanto, em 57 dias, o processo especulativo foi vencido. A confiança no banco central cresceu tanto na Alemanha como no exterior: "Havíamos readquirido nossa idoneidade

(14) Nascia ali uma grande amizade com o banqueiro inglês. Um dos netos de Schacht seria batizado pelo próprio Norman, recebendo o nome de Norman Schacht. Montagu Norman foi presidente do Banco da Inglaterra durante vinte anos, sendo "intocado pelos diversos governos ingleses" (Schacht, 1999, p. 256).

(15) O banco estatal Golddiskontbank seria o correspondente no Brasil ao BNDES. 
creditícia internacionalmente. A reputação da Alemanha como parceiro comercial honesto estava salva" (Schacht, 1999, p. 270). ${ }^{16}$

O Plano Dawes foi assinado por ambas as partes em agosto de 1924, porém o total das reparações não foi fixado. O relatório final do Plano tinha os seguintes pontos principais: a) reforma monetária para estabilizar o marco (já realizada por Schacht); b) criação de novos impostos, para sanear o déficit público; c) revisão dos valores das reparações (o montante a ser pago anualmente seria de 1 bilhão de marcos-ouro nos quatro primeiros anos, e depois 2,5 bilhões pelos anos seguintes); d) empréstimos oferecidos pelos Estados Unidos; e) a França retiraria parte de suas tropas da Alemanha; f) reestruturação do Reichsbank, com a introdução de um grêmio fiscalizador (Schacht, 1999; Bubholz e Dasista, 2002). ${ }^{17}$

O Plano Dawes concedeu um empréstimo de 800 milhões de marcos-ouro em divisas estrangeiras ao Reichsbank, o que possibilitou os recursos para a manutenção dos pagamentos externos da Alemanha. Sobre esse momento, escreveu Schacht: "Fiquei satisfeito por ter contribuído para a recuperação da confiança internacional na Alemanha. Nosso crédito estava novamente consolidado. Agora, tratava-se de não fazer mau uso dele. Para mim estava totalmente claro que a Alemanha tinha de comprar do exterior matérias-primas, alimentos e certamente algumas máquinas, para a reconstrução de sua indústria. Aceitar créditos estrangeiros para tal objetivo era uma oferta totalmente razoável. Mas os créditos não deveriam ultrapassar o limite imposto por aquele objetivo" (Schacht, 1999, p. 272). Com o Plano Dawes, o mandato de presidente do Reichsbank deixava de ser vitalício e passava para períodos de quatro anos.

O Plano Dawes e o respeito que o Reichsbank adquiriu sob o comando de Schacht recolocavam a Alemanha de volta ao mercado internacional de créditos. O sucesso econômico da economia alemã a partir de 1924 fez com que o país atraísse uma enorme quantidade de capitais externos. Empréstimos eram concedidos sem muita restrição por parte dos banqueiros estrangeiros. ${ }^{18}$ Além de empresas privadas e públicas, cidades e comarcas tomavam empréstimos externos para

(16) Uma carta de Mr. Bates (secretário do Plano Dawes) a Owen D. Young nos mostra a situação vivida na época: "Desde janeiro deste ano, Schacht foi um baluarte em Berlim no pleno sentido da palavra (...) Para evitar uma nova inflação recusou-se a conceder crédito a tal ponto que alguns ramos da economia alemã fracassaram. Apesar de cartas de ameaça, crítica aberta e oposição política provou, sem pestanejar, uma coragem extraordinária" (Bates citado por Schacht, 1999, p. 272).

(17) Este grêmio fiscalizador do pagamento das reparações de guerra era constituído de sete alemães e sete estrangeiros, e foi dirigido por Parker Gilbert. Durou até 1930, sem que houvesse nenhuma divergência grave com o Reichsbank (Schacht, 1931, 1999). Constantino Bresciani-Turroni foi membro desse grêmio fiscalizador, e posteriormente escreveu "Economia da Inflação", em 1931.

(18) "Os empréstimos foram praticamente impostos à Alemanha pelos agentes financeiros e bancos internacionais. Os agentes estrangeiros batiam às portas dos donos de indústrias e dos municípios oferecendo empréstimos" (Schacht, 1999, p. 275). 
investir em obras públicas, que não rendiam divisas estrangeiras para o seu futuro pagamento. Esses recursos externos acabavam servindo para pagar as reparações de guerra: "Emprestavam dinheiro a firmas alemãs, empresas públicas, estatais, comarcas e cidades na Alemanha. O dinheiro estrangeiro era trocado pelo Reichsbank por dinheiro alemão, mas aquele formava o fundo do qual as reparações eram transferidas. Assim, os políticos estrangeiros recebiam o dinheiro que os capitalistas estrangeiros haviam emprestado à Alemanha" (Schacht, 1999, p. 295). A Alemanha pagava as reparações com “(...) dinheiro emprestado e não com os excedentes de exportação. Era só questão de tempo, até que a Alemanha não tivesse mais condições de efetuar pagamento em moeda estrangeira" (Ibid., p. 296).

Schacht enxergava que os empréstimos externos deveriam servir para as empresas que quisessem exportar sua produção, gerando, assim, as divisas necessárias ao seu pagamento. Durante sua permanência na presidência do Reichsbank, Schacht combateu a tomada de empréstimos desnecessários, para investimentos improdutivos. Tentou exigir que esses empréstimos fossem autorizados pelo Reichsbank, visando controlá-los, mas não obteve sucesso. A dívida externa aumentou sem cessar até a crise de 1931: “Todos os seis anos de meu primeiro mandato na presidência do banco foram utilizados para a luta pelo controle de nossa dívida externa" (Ibid., p. 274).

Entendia também que os empréstimos externos estavam servindo para a compra de bens industriais no exterior, o que prejudicava a criação interna de empregos: "Moeda estrangeira só pode ser gasta no exterior. Provoca o aumento das importações, especialmente produtos manufaturados. A manufatura alemã seria penalizada, o que geraria desemprego" (Ibid., p. 274). O desemprego permaneceu elevado na segunda metade dos anos 1920 (acima de 1 milhão de desempregados), mesmo com a economia alemã crescendo consideravelmente. Segundo Fano (1981), o aumento da produtividade na indústria alemã era o principal responsável pelo desemprego elevado naquela época.

Com o tempo, o agente das reparações, Parker Gilbert, percebeu que as reparações não estavam sendo realmente pagas, pois a Alemanha quitava suas dívidas com o dinheiro emprestado, e não com os excedentes da balança comercial. Diante de tal situação, foi convocada uma nova conferência, preparada durante o ano de 1928 e realizada em fevereiro de 1929, novamente em Paris.

Presidida pelo financista norte-americano Owen Young, a Conferência tinha duas questões importantes para serem resolvidas. A primeira referia-se ao valor que a Alemanha deveria pagar de reparações ao ano; a segunda dizia respeito à capacidade da Alemanha de transferir essa quantia em moeda estrangeira, de modo a não prejudicar o crescimento de sua economia. Schacht utilizou uma tática 
de cansar os participantes da conferência, e com isso conseguir reduzir ao máximo possível o montante da reparação, e adiar a questão sobre as transferências. ${ }^{19}$

Durante a Conferência Young, Schacht propôs a criação de um banco internacional que seria responsável pela distribuição dos pagamentos das reparações, mas que também fornecesse empréstimos aos países subdesenvolvidos para que pudessem se industrializar e, dessa forma, comprar os equipamentos da Alemanha. Com isso, o país teria divisas para pagar as reparações:

Gostaria de propor-lhe no Plano Young o compromisso de todos os participantes de instituírem conjuntamente um banco, pelo qual, por um lado, os pagamentos de reparações devam ser distribuídos, e, por outro, porém, tenha a tarefa de executar operações financeiras internacionais, pelas quais fluam verbas aos países subdesenvolvidos, a fim de que possam explorar suas matérias-primas naturais e aumentar sua produção agrícola. Com a ajuda financeira, esses países estariam em condições de comprar as instalações industriais, necessárias para o aumento de produção, especialmente da Alemanha (Schacht, 1999, p. 315).

A proposta de Schacht foi incluída no Plano Young. Depois de semanas de negociações, o presidente da conferência exigiu que os representantes alemães apresentassem um memorando de quanto poderiam transferir em moeda estrangeira aos países aliados. Pressionados, os representantes alemães, sob o comando de Schacht, apresentaram o memorando que afirmava "(...) que a perda das regiões orientais para a Polônia limitou drasticamente a fonte de alimentação da Alemanha, prejudicando sensivelmente a solvência alemã" (Ibid., p. 303) e que a Alemanha teria condições de aumentar os pagamentos de reparações caso tivesse a “(...) possibilidade de adquirir matérias-primas de ultramar com nossa própria moeda, o que porém nos fora tirado com a tomada das colônias" (Ibid., p. 303). O memorando provocou grande agitação na Conferência, pois parecia que a Alemanha queria de volta seus territórios e colônias perdidos no Tratado de Versalhes. Tanto a imprensa dos países aliados como a da própria Alemanha criticaram os representantes alemães.

No final da Conferência, Schacht não queria assinar o Plano Young, porque achava "inexeqüível" o valor estipulado das reparações: "Estava claro para todos, com exceção de alguns fanáticos, que o Plano Young era um absurdo econômico" (Ibid., p. 311). No entanto, o governo alemão deu ordens para que ele

(19) Os representantes franceses, percebendo a tática de Schacht de prolongar as negociações sem nenhum resultado prático, armaram uma represália contra a Alemanha. De um dia para outro, todos os bancos franceses que mantinham crédito em Berlim solicitaram de volta os seus créditos. A medida provocou uma rápida redução das reservas cambiais e em ouro do Reichsbank, abalando a estabilidade do reichsmark. Schacht usou isso a seu favor, demonstrando que, se um movimento especulativo de uma moeda fraca como a francesa abalava o sistema monetário alemão, tudo isso apenas serviria para comprovar a fragilidade da economia alemã, reforçando que a mesma não poderia pagar as reparações. No dia seguinte, os bancos franceses revogaram a decisão de tirar seus depósitos da Alemanha (Schacht, 1931, 1999). 
assinasse o acordo, pois libertaria a região da Renânia da ocupação aliada e melhoraria o clima entre as partes. Assinado no dia 7 de julho de 1929, o Plano Young reduziu as reparações em média a 1,5 bilhão de marcos-ouro por ano, os controladores estrangeiros saíram da Alemanha, os bens sob administração externa foram liberados e ficou aprovada a criação de um banco de compensações de pagamentos. Não obstante, o grande fator negativo era o valor estipulado para as reparações: 121 bilhões de reichsmark (US\$ 26,4 bilhões), a serem pagos em 58 anos (Schacht, 1931, 1999).

Entre outubro e novembro de 1929, os membros do Plano Young se reuniram na cidade alemã de Baden-Baden para criar o Bank for International Settlements (BIS). Foi Schacht quem sugeriu que o banco fosse sediado na Suíça. A cidade escolhida foi Basiléia. Na prática, o banco limitou-se a distribuir os pagamentos de reparações entre os aliados e a executar a cooperação entre os bancos centrais. Entretanto, a quebra da bolsa de valores de Nova York, nessa época, ofuscou a criação do BIS.

Segundo Schacht (1950, p. 50), os empréstimos externos feitos à Alemanha nos anos 1920, principalmente por particulares dos Estados Unidos, foram utilizados para pagar as reparações aos governos da Inglaterra, França e países aliados. De acordo com o BIS, entre 1924 e 1930, a Alemanha recebeu 18 bilhões de reichsmark de empréstimos estrangeiros: 10,3 bilhões foram usados para pagar as reparações e o restante foi gasto em consumo e investimentos públicos, ou seja, em coisas que não geravam divisas estrangeiras. A moeda estrangeira foi gasta, inclusive, em produtos estrangeiros que poderiam ter sido fabricados na Alemanha: "Desse modo, o abuso na contratação de dívidas no estrangeiro contribuiu notavelmente ao aumento da desocupação no território alemão" (Ibid., p. 54-55).

No dia 2 de abril de 1930, Schacht pediu demissão da presidência do Reichsbank, por não concordar com as novas renegociações do Plano Young, que eram prejudiciais à Alemanha. $\mathrm{O}$ presidente da Alemanha, Sr. Hindenburg, nesse mesmo dia escreveu para Schacht: "Seu nome sempre será mencionado em primeiro lugar entre aqueles que podem requerer para si o mérito de recriação de uma moeda forte" (Hindenburg citado por Schacht, 1999, p. 332).

Schacht foi morar em sua casa de campo em Guhler, adquirida em 1926. O seu pensamento girava em torno das reparações de guerra, prejudiciais não só à Alemanha, mas a todo o comércio mundial. Foi convidado para uma série de palestras em várias cidades do mundo (Bucareste, Berna, Copenhague e Estocolmo) cujo tema era sempre a "luta contra as reparações". Além disso, proferiu cerca de 50 palestras nos Estados Unidos, sendo recebido pelo presidente norte-americano Herbert Hoover, no final de 1930. Foi o próprio Hoover, seis 
meses depois, em junho de 1931, que fez a proposta de moratória dos pagamentos do Plano Young aos governos aliados. Seria o fim das reparações (Schacht, 1931, 1999).

Durante suas palestras nos Estados Unidos, Schacht advertiu que as reparações empobreciam o povo alemão e estavam levando ao poder partidos da extrema direita e extrema esquerda, ou seja, o Partido Nacional Socialista (de Adolf Hitler) e o Partido Comunista. Ainda nos Estados Unidos, foi convidado a escrever um livro sobre suas palestras. "O fim das reparações" foi lançado em 1931 nos Estados Unidos, Inglaterra e Alemanha.

\section{0 ministro da economia de Hitler e a grande depressão ${ }^{20}$}

A crise econômica iniciada em 1929 nos Estados Unidos começou a se espalhar pelo mundo. As advertências de Schacht sobre os altos empréstimos tomados no exterior se fizeram sentir. Em março de 1931, o maior banco da Áustria não teve mais condições de pagar suas dívidas externas. Teve início uma retirada de créditos concedidos à Alemanha. As reservas cambiais e em ouro do Reichsbank se reduziram rapidamente.

Em 31 de junho, Schacht propôs que o Reichsbank declarasse moratória para evitar a retirada das reservas estrangeiras do país. Seu conselho não foi aceito e em poucos dias as reservas do Reichsbank se esgotaram. De todos os bancos alemães, o Danat-Bank era o que estava em piores condições. A quebra da Sociedade Algodoeira do Norte, um dos principais devedores do Danat-Bank, levou o banco a interromper seus pagamentos.

No dia 13 de julho, Schacht foi chamado às pressas pelo chanceler alemão, Sr. Bruning, que lhe pediu que assumisse o cargo de secretário do governo para assuntos bancários, visando resolver a crise bancária. Schacht agradeceu, mas recusou o convite, dizendo que essa tarefa cabia ao presidente do Reichsbank.

Assim, a crise internacional dos anos 1930 atingiu a Alemanha em julho de 1931. Houve a falência de vários bancos e os empréstimos estrangeiros não foram pagos: "Quem sofreu foram os poupadores estrangeiros que haviam subscrito os empréstimos estrangeiros, confiando nas recomendações dos bancos" (Schacht, 1999, p. 276). ${ }^{21}$

(20) Esta seção está baseada, em parte, em Schacht (1999).

(21) Em rigor, a crise econômica alemã teve início no final de 1928, quando capitais de curto prazo abandonaram o país, indo buscar a maior lucratividade da bolsa norte-americana. Em 1930, cerca de três milhões de trabalhadores já estavam desempregados, segundo o editor da revista Der Deutsche Volkwirt, Gustav Stolper: "Dos quase 3 milhões de desempregados que afligem a Alemanha neste verão, 1 milhão pode ser vítima da crise internacional. O resto é vítima dos desatinos da política financeira e econômica alemã, do fracasso da razão e da vontade de reforma e de ajuda, onde estas são possíveis" (Stolper citado por Schacht, 1999, p.359). 
Um novo choque ocorreu quando o governo inglês decretou a desvalorização da libra esterlina, em 20 de setembro de 1931:

Com isso iniciou-se a era das desvalorizações monetárias que se estendeu para uma série de países, inclusive os Estados Unidos, e se repetiu mais tarde, por último, na Inglaterra. Assim, fidelidade e confiança foram definitivamente eliminadas das transações internacionais financeiras e de crédito (Schacht, 1999, p. 355). ${ }^{22}$

A crise econômica quebrou não só bancos, mas também muitas empresas alemãs. O desemprego, que já era alto, subiu ainda mais. Em 11 de outubro de 1931, Schacht fez o seguinte discurso num encontro com todos os partidos e associações de tendência nacionalista: "Uma diminuição da produção em quase um terço, um alto índice de desemprego que se torna um fenômeno duradouro, uma dívida interna que se expressa diariamente nos números de concordatas, uma dívida externa que impossibilita um pagamento no vencimento, uma moeda que não serve mais para a circulação regular de mercadorias, mas apenas para ocultar a falta de liquidez de nossas instituições financeiras e do setor público, esta é a situação alemã" (Ibid., p. 358). Para a solução da crise, propõe: "O programa a ser executado pelo governo nacional baseia-se em poucos pontos básicos. É o programa de Frederico, o Grande, após a guerra dos sete anos: firmar-se na própria economia, tirar do próprio solo tudo o que é possível tirar e, de resto, restringir-se, economizar e trabalhar durante uma geração. Pedir emprestado e mendigar torna desprezível, torna incapaz de negociar, torna incapaz de aliar-se" (Ibid., p. 359).

Em meados de junho de 1932, o desemprego chegava à casa de 6 milhões de trabalhadores, cerca de $40 \%$ da força de trabalho alemã. ${ }^{23}$ As eleições de julho levaram o Partido Nacional-Socialista Alemão a se tornar o maior partido do parlamento alemão. Seu líder era o austríaco Adolf Hitler (1889-1945). Em janeiro de 1933, na iminência de Hitler se tornar chanceler, o cargo foi oferecido a várias personalidades alemãs, inclusive a Schacht, que o recusou. No final do mês, sem alternativa, dada a força política obtida nas urnas, o presidente alemão, Sr. Hindenburg, nomeia Hitler como novo chanceler. ${ }^{24}$

(22) Inglaterra, França, Estados Unidos e outros países desvalorizaram suas moedas no início dos anos 1930. A Alemanha não. O principal motivo era o medo da volta da inflação, já que mais de $20 \%$ das importações eram de matérias-primas e alimentos (Schacht, 1950, p.65-66).

(23) "Enquanto isso, o índice de desemprego não cessava de aumentar. As tentativas, iniciadas por Bruning e prosseguidas por Papen, de gerar empregos com a ajuda do governo federal com encomendas através de letras de câmbio não alteraram muito o quadro, porque o volume da ajuda era totalmente insuficiente diante dos milhões de desempregados" (Schacht, 1999, p. 361).

(24) Sobre o que levou Hitler a assumir o poder, escreveu Victor Schiff (líder do partido socialdemocrata), em junho de 1934: "Se existe um ponto sobre o qual não existem divergências de opinião entre nós, e não poderá existir, então é certamente que Hitler deve sua ascensão e finalmente sua vitória essencialmente à crise econômica mundial: ao desespero dos proletários desempregados, da juventude universitária sem futuro, dos comerciantes e artesões de classe média indo à falência e dos agricultores seriamente ameaçados pela queda dos preços. Neste sentido, todos nós fracassamos realmente. Com certeza atribuímos, com razão, a responsabilidade da crise à ordem econômica capitalista, mas, além disso, não fomos capazes de oferecer às massas mais do que palavrório socialista" (Schiff citado por Schacht, 1999, p. 363). 
O primeiro contato de Schacht com Hitler ocorreu num jantar na casa de Hermann Göring, em 5 de janeiro de 1931. Hitler já era o líder do segundo maior partido alemão no parlamento. Segundo Schacht, "já naquele primeiro encontro me ficou claro que a força propagandística de Hitler teria chances imensas junto ao povo alemão, caso não se conseguisse superar a crise econômica e afastar as massas do radicalismo. Hitler era possuído pelo que dizia, um autêntico fanático com o mais intenso efeito sobre os ouvintes, um agitador nato, apesar de sua voz às vezes rouca e não raramente esganiçada" (Schacht, 1999, p. 346).

Nos encontros que teve com membros do partido de Hitler, Schacht ficou preocupado com as idéias funestas daqueles indivíduos: "Meus vários encontros, com defensores da política econômica nacional-socialista, entre eles eventuais conversas com Gottfried Feder, levaram-me a questionar o que seria da economia alemã se aquelas teorias econômicas fossem colocadas em prática" (Ibid., p. 350). Diante disso, Schacht percebeu que não poderia se isolar: "Comecei a refletir se era responsável de minha parte manter-me tão afastado da vida pública como até então" (Ibid., p. 350). Sentia responsabilidades com a nação, independentemente do governo da época: "Por isso, dei a entender a Hitler, verbalmente e por escrito, que não me recusaria a cooperar, caso ele assumisse o poder. Isso mais tarde seria levado a mal. Mas nunca encontrei em lugar algum, nem na época, nem posteriormente, uma explicação do que mais poderia ter sido colocado no lugar do chanceler Hitler" (Ibid., p. 362).

O desemprego preocupava o chanceler Adolf Hitler. Chamou Schacht e perguntou se o Reichsbank teria condições de providenciar o dinheiro para combater o desemprego. Schacht disse que o Reichsbank deveria gastar todo o dinheiro necessário "para tirar o último desempregado da rua" (Ibid., p. 369). Dessa conversa, Hitler convidou Schacht para reassumir a presidência do Reichsbank: em 17 de março de 1933, Schacht era reempossado no cargo. Estava com 56 anos. $^{25}$

Para financiar a criação de empregos e a recuperação da economia alemã, Schacht evitou uma emissão volumosa de papel-moeda que pudesse ressuscitar um novo processo inflacionário, fato com o qual o povo alemão não iria concordar sem se manifestar, dado o passado recente da hiperinflação. Assim, elaborou o que ficou conhecido como "Saques Mefo": como o governo não tinha naquele momento credibilidade necessária para captar recursos mediante a emissão de

(25) "O trabalho diante do qual o governo de Hitler foi colocado não era fácil. O índice de desemprego subira, do seu nível mais baixo no verão de 1927, ano após ano, monstruosamente, e atingiu seu ponto mais alto no inverno de 1931-32. No verão seguinte, não caiu muito mais e apresentou no inverno próximo novamente tendência de alta. O setor mais atingido pelo desemprego foi a construção civil, no qual quase $90 \%$ estavam desempregados. O desemprego não poderia ser combatido sem grandes obras públicas e sem verbas maiores" (Schacht, 1999, p. 368). 
títulos públicos, Schacht forjou a criação da Mettalurgische Forschungsgesellschaft m.b.H. - Mefo, em maio de 1933. Tratava-se de uma sociedade anônima formada pelas quatro grandes empresas alemãs (Siemens, Gutehoffnungshütte, Krupp e Rheinmetall), com capital inicial de 1 milhão de marcos.

Essa empresa privada emitiria títulos (Saques Mefo), garantidos pelo governo, e que poderiam ser descontados na rede bancária alemã, depois de determinado prazo. Os bancos, por sua vez, poderiam trocar os Saques Mefo por marcos diretamente no caixa do Reichsbank, respeitando também certos prazos. Os títulos pagariam juros de $4 \%$ ao ano. O governo alemão, de posse desses títulos, passou a pagar suas despesas com as empresas fornecedoras por meio dos Saques Mefo, sem emitir papel-moeda. As empresas, entretanto, preferiram não descontar os títulos, pois rendiam juros anuais significativos para uma economia estabilizada.

Em poucos meses foram emitidos 4 milhões de marcos em Saques Mefo. Um sucesso! Os recursos foram aplicados imediatamente em obras públicas e, posteriormente, no rearmamento. Em quatro anos (1934 a 1938), o volume chegou a 12 milhões de marcos. Schacht soube entender o que mais tarde ficou conhecido por multiplicador keynesiano: os Saques Mefo geravam demanda efetiva e, portanto, aumentavam a produção e o volume de emprego; quando descontados por marcos no Reichsbank, depois de certo tempo, não tinham efeitos inflacionários, pois a recuperação da produção permitia uma maior quantidade de papel-moeda em circulação. Em suas memórias, Schacht descreveu com orgulho o mecanismo dos Saques Mefo:

No que diz respeito à praticabilidade do sistema, o governo podia pagar as encomendas que fazia à economia privada, e que posteriormente se estenderam em especial para o rearmamento, com os saques Mefo. Os fornecedores podiam trocar os títulos imediatamente por dinheiro no Reichsbank (...) Ocorreu que, como eu havia esperado, o dinheiro parado nos caixas e bolsos das empresas, que não se queria ou não se podia aplicar a longo prazo, foi utilizado imediatamente para essa aplicação de curto prazo. Como os saques davam $4 \%$ de juros e podiam ser trocados a qualquer momento pelo Reichsbank, substituíam, por assim dizer, o caixa em espécie, que de resto era mantido, e além disso ofereciam o lucro dos juros. Esse sistema tornou possível que cerca de seis milhões de marcos em saques Mefo, cuja circulação total em quatro anos aos poucos subiu para 12 milhões de marcos, fossem absorvidos pelo mercado, não indo portanto para o Reichsbank. Com isso evitou-se qualquer efeito inflacionário do financiamento da geração de empregos e qualquer desvalorização monetária (Schacht, 1999, p. 385-386).

O historiador William Shirer, que em nada simpatizava com Schacht e o culpava pelo rearmamento alemão, teve que se render ao sucesso do manejo da moeda pelo banqueiro central alemão: 
Toda a sabida magia de Schacht nas finanças foi posta a trabalhar para custear a preparação do Terceiro Reich para a guerra. As emissões de títulos bancários constituíram apenas um de seus expedientes. Manipulava a moeda de modo tão mágico que certa vez economistas estrangeiros estimaram que ela tinha 237 valores diferentes. Promoveu trocas lucrativas (para a Alemanha) surpreendentes com dezenas de países e, para estupefação dos economistas ortodoxos, provou com êxito que quanto mais se devia a um país mais negócios se realizavam com ele. Sua instituição de crédito num país que tinha pequeno capital líquido e quase nenhuma reserva financeira, foi obra de gênio ou, como alguns dizem, de manobras de mestre. A criação das letras 'mefo' representa um bom exemplo. Eram letras criadas simplesmente pelo Reichsbank e garantidas pelo Estado, sendo utilizadas para pagar os fabricantes de armamentos. As letras eram aceitas por todos os bancos alemães e finalmente descontadas pelo Reichsbank. Desde que não apareceram, nem nos relatórios publicados pelo banco central nem no orçamento governamental, elas ajudaram a manter segredo quanto às dimensões do rearmamento da Alemanha. De 1935 a 1938 foram utilizadas exclusivamente para financiar o rearmamento e atingiram um total de doze milhões de marcos (Shirer, 1964a, p. 387).

Entendendo que a construção civil era grande absorvedora de mão-deobra, Schacht liberou verbas para construção de diques, canalizações, estradas, desmatamento, drenagens, moradias populares, hospitais, asilos, entre outras construções. Ficou famosa a construção das imensas autobahns - auto-estradas seguras de alta velocidade que cruzaram toda a Alemanha. Em poucos meses os resultados apareceram: o desemprego havia caído vertiginosamente em todo o país, e em alguns distritos o desemprego havia até terminado. ${ }^{26}$

A grande depressão fez com que as nações aumentassem suas taxas de importação, impusessem quotas de importação e desvalorizassem suas moedas. Essas medidas prejudicaram as exportações alemãs, e assim impediram o pagamento de juros dos empréstimos tomados nos anos $1920 .^{27}$

Num encontro com Hitler, este lhe perguntou como se poderia melhorar a situação cambial do país. Schacht respondeu: "Nunca comprar mais do que posso pagar e, se possível, compraria dos países que compram de mim” (Schacht, 1999, p. 387). Em 27 de julho de 1934, com a saída do ministro da Economia por problemas de saúde, Hitler convidou Schacht para assumir o ministério, em conjunto com a presidência do Reichsbank. Assumiu o cargo no dia 2 de agosto de

(26) A média anual do desemprego na Alemanha nesse período foi a seguinte: 1930: 3,076 milhões; 1931: 4,520 milhões; 1932: 5,575 milhões; 1933: 4,804 milhões; 1934: 2,718 milhões; 1935: 2,151 milhões; 1936: 1,593 milhão; 1937: 912 mil; 1938: 429 mil; 1939: 119 mil (DHM, 2005).

(27) Em maio de 1933, Schacht foi indicado para representar a Alemanha na preparação da Conferência Econômica Mundial, nos Estados Unidos. Teve quatro encontros com o presidente norte-americano Franklin Roosevelt. $\mathrm{O}$ assunto central era a estabilização monetária e as medidas político-comerciais que poderiam ser tomadas para reaquecer o comércio mundial. Segundo Schacht (1999, p.380-381), faltou à conferência uma verdadeira coordenação. Entre junho e julho de 1933, ocorreu a Conferência Econômica Mundial, em Londres, sem nenhum resultado prático que pudesse solucionar a grande depressão (Schacht, 1999, p. 375). 
1934. ${ }^{28}$ Nesse mesmo mês, após a morte do presidente Hindenburg, Hitler unificou os cargos de chanceler e presidente.

Nessa época, a Alemanha tinha dificuldades em atender à demanda por alimentos de sua grande população, dada a quantidade reduzida de solos agriculturáveis. Dependia das exportações industriais para importar alimentos. Cabia a Schacht providenciar as divisas para a importação de alimentos. Para tanto, elaborou o programa de comércio exterior chamado "Novo Plano", em setembro de 1934. Baseado no comércio bilateral, o plano conseguiu prover satisfatoriamente as divisas para a importação de alimentos. ${ }^{29} \mathrm{O}$ "Novo Plano" de Schacht foi muito criticado no exterior, pois contrariava tanto o multilateralismo comercial como a teoria econômica clássica. ${ }^{30}$ Em setembro de $1935,83 \%$ do comércio alemão era efetuado por meio de trocas e somente $17 \%$ eram pagos com moeda estrangeira.

No ano seguinte, Hitler lançou o segundo plano quadrienal, e convocou Hermann Göring para sua execução (setembro de 1936). Schacht era contra os planos quadrienais. Para ele, os planos eram propaganda política: "Alcançavam uma mínima parte de seu objetivo" (Schacht, 1999, p. 616). Era favorável a tarefas anuais. Foi nessa data que Schacht começou a perder sua influência sobre Hitler. ${ }^{31}$

(28) "Hitler me concedeu no Ministério a mesma liberdade e autonomia que tinha no Reichsbank. Não entendia absolutamente nada de economia. Contanto que eu mantivesse a balança comercial em ordem e providenciasse as divisas necessárias, não se preocupava como eu conseguia fazê-lo. Até o outono de 1936, Hitler não tolerou nenhuma medida que me atingisse em meu trabalho. Depois houve o chamado "segundo Plano Quadrienal', que provocou rapidamente minha saída do Ministério da Economia” (Schacht, 1999, p. 398).

(29) "Nos contratos comerciais com uma série de países estrangeiros as compras alemãs foram creditadas em contas de compensação nos respectivos países e deixou-se a critério destes utilizarem esses créditos novamente para compras no mercado alemão (...) Na primavera de 1938 tínhamos esses contratos de compensação com nada menos que 25 países, de forma que mais da metade do comércio exterior alemão acontecia por esses canais. Através desse sistema de comércio bilateral conseguimos atender à demanda alemã de matérias-primas e alimentos" (Ibid., p. 398-399).

(30) "Fui intensamente atacado no exterior por causa dessa política, que contrariava, na verdade, as posições tradicionais de transações comerciais multilaterais e de tratamento preferencial. Cientistas de todos os países classificaram esse sistema de violação de qualquer teoria econômica clássica. Contudo, a mim não interessava se minha teoria econômica era clássica, mas sim se a demanda de alimentos do povo alemão estava atendida" (Ibid., p. 399).

(31) "Desde meados de 1936, meu relacionamento com Hitler havia piorado lenta, porém constantemente. Minha influência sobre sua política, que fora bem-sucedida em particular na área econômica, diminuíra rapidamente após a primeira metade de 1936. Minha comunicação de março de 1937 de que não deveria esperar mais dinheiro de minha parte, a impossibilidade de expandir seus planos de autarquia para o setor dos alimentos, o esgotamento total do mercado de capitais, demonstrado a ele pelo Reichsbank, e meu repúdio à política anti-semita do partido, tudo isso evidentemente o convencera de que comigo não poderia prosseguir seus planos bélicos, até então secretos. Só no processo de Nuremberg tomei conhecimento de que, no começo de novembro de 1937, Hitler já revelara, sigilosamente, seus planos militares aos chefes da Wehrmacht e ao ministro do Exterior. Portanto, eu ainda estava confiante, não podia e nem queria desistir da esperança de um desenvolvimento pacífico. O reconhecimento do contrário veio no começo de janeiro de 1938." (Ibid., p.459). Schacht perdeu a esperança de orientar Hitler para a paz em janeiro de 1938: "Lentamente amadureceu em mim a convicção de que apenas um golpe poria fim ao regime hitlerista" (Ibid., p.462). 
Em agosto de 1937, Schacht enviou uma carta a Göring, criticando seus gastos internos, que estavam prejudicando as exportações. Por discordar da política econômica de Göring, Schacht pediu demissão de seu cargo de ministro da Economia (setembro de 1937). Hitler não aceitou seu pedido. Solicitou que Schacht se entendesse com Göring. Como o entendimento não se concretizou, Hitler aceitou sua demissão em novembro de 1937, mas nomeou Schacht para um novo ministério, que só existiria no papel. Göring assumiu o ministério da Economia. Apesar do confronto com Göring, Schacht continuava sendo o todopoderoso presidente do banco central alemão. ${ }^{32}$

Diante da impossibilidade de lançar novos empréstimos ao público, Hitler sugeriu a Schacht a emissão de moeda para cobrir os gastos com armamento. A resposta da direção do Reichsbank foi dada por escrito, em 7 de janeiro de 1939:

A moeda vem sendo ameaçada substancialmente pelos gastos desmedidos do setor público. $\mathrm{O}$ aumento desenfreado dos gastos públicos aniquila qualquer tentativa de um orçamento equilibrado, leva as finanças públicas à beira da falência, apesar do aumento imenso da carga tributária, e arruína com isso o banco de emissão e a moeda. Não existe receita, por mais genial e refinada, nem sistema de técnica financeira e monetária, nem organização e nem medidas de controle que sejam suficientemente eficientes para deter os efeitos arrasadores, sobre a moeda, de uma administração de despesas descontrolada. Nenhum banco de emissão é capaz de manter a moeda, contra uma política de gastos inflacionária por parte do Estado (Schacht, 1999, p. 435).

Em razão desse comunicado, Schacht foi demitido da presidência do Reichsbank, em 20 de janeiro de 1939. Analisando a sua autobiografia, de 1953, percebe-se que as discussões entre Schacht e Hitler tinham como centro a estabilidade monetária e o aumento de gastos com rearmamento. Enquanto Hitler queria aumentar os gastos, principalmente com armamento, Schacht se recusava a isso, por temer uma volta da inflação. Na conversa com Hitler, no dia de sua demissão do Reichsbank, o chanceler finalizou: "E o que o senhor acredita, Sr. Schacht, não vai acontecer. Não haverá inflação" (Hitler citado por Schacht, 1999, p. 466). Seu último encontro com Hitler se deu em fevereiro de 1941. Hitler

(32) O historiador William Shirer relata em seu livro que Schacht foi contra o aumento de despesas para o rearmamento, pois a situação financeira do Estado alemão já estava no limite. Perdendo a disputa para Hermann Göring, Schacht pediu demissão a Hitler: "O Führer relutou em aceitá-la, em vista da reação desfavorável que com certeza a saída de Schacht provocaria, tanto internamente como no exterior, mas o maltratado ministro estava inflexível e Hitler, finalmente, concordou em demiti-lo, ao fim de dois meses. A 5 de setembro, Schacht entrou em gozo de licença, e sua renúncia foi formalmente aceita em 8 de dezembro. Em face da insistência de Hitler, Schacht permaneceu no ministério como ministro sem pasta e ficou com a presidência do Reichsbank, mantendo, assim, as aparências, e amortecendo o choque com a opinião alemã e mundial. Sua influência como freio ao febril rearmamento de Hitler para a guerra, contudo, tinha chegado ao fim, embora continuasse no ministério e no Reichsbank, emprestando a aura de seu nome e de sua reputação aos propósitos de Hitler" (Shire, 1964b, p. 55). 
perguntou-lhe se valia a pena viajar até os Estados Unidos para negociar um acordo de guerra. Schacht disse que não! ${ }^{33}$

Vivendo em sua casa de campo, sem nenhum poder e nenhuma influência sobre o destino da Alemanha, Schacht pediu demissão de seu "ministério sem pasta" em fevereiro de 1942. Sua demissão, novamente, não foi aceita por Hitler. Passado quase um ano desse episódio, Schacht escreveu uma carta a Göring, criticando seu projeto de convocar estudantes de 15 anos para o serviço militar. Tomando conhecimento da carta, Hitler decretou, finalmente, a demissão de Schacht em janeiro de 1943. Estava com 67 anos.

Descontente com a situação da Alemanha durante a guerra, participou de um plano para assassinar Hitler. $\mathrm{O}$ fracasso do atentado levou seus mentores para a cadeia, inclusive Schacht, em julho de 1944. Logo depois, todos os conspiradores foram executados, menos Schacht, que continuou preso. Schacht nunca soube o motivo de ter sido poupado por Hitler. Entretanto, existem especulações: seria por gratidão de Hitler pelos serviços prestados durante a Grande Depressão? Ou Hitler ainda contava com ele para reorganizar a economia européia, depois de terminada a guerra, tendo a Alemanha como vencedora?

O fato é que até maio de 1945 Schacht ficou encarcerado em prisões alemãs. Depois dessa data, foi preso pelos aliados. Absolvido pelo tribunal de Nuremberg, em outubro de 1946, foi novamente preso pelos alemães. Schacht só seria libertado, definitivamente, em setembro de 1948, aos 71 anos de idade. ${ }^{34}$

(33) Segundo Franco (1999, p. 30), o mundo inteiro acostumou a ver Schacht como o "czar econômico do nazismo e um dos mais poderosos e influentes homens do Führer".

(34) Shirer (1964a, p. 386-387) afirma com convicção, baseado em documentos oficiais escritos por Schacht, que o presidente do Reichsbank teve papel fundamental no rearmamento alemão para a guerra: "Na secreta Lei de Defesa de 21 de maio de 1935, ele [Hitler] nomeou Schacht General Plenipotenciário para a Economia de Guerra, ordenando-lhe 'começar seu trabalho ainda no período de paz' e dando-lhe autoridade para 'dirigir os preparativos econômicos para a guerra'. O inimitável Dr. Schacht não aguardou até a primavera de 1935 para iniciar a edificação da economia alemã para a guerra. A 30 de setembro de 1934 (...) submeteu um relatório ao Führer, sob o título 'Relatório sobre o estado do trabalho para a mobilização da economia de guerra, a partir de 30 de setembro de 1934', no qual orgulhosamente acentuava que seu ministério 'fora encarregado da preparação econômica para a guerra'. No dia 3 de maio de 1935, quatro semanas antes de ser designado General Plenipotenciário para a Economia de Guerra, Schacht entregou um memorando especial a Hitler, que começa com a afirmação de que 'o cumprimento do programa de armamento com rapidez e em quantidade é o fundamental da política alemã; tudo o mais, portanto, deverá ficar subordinado a esse objetivo (...)'. Schacht explicou a Hitler que, já que 'o armamento tinha de ser completamente camuflado até 16 de março de 1935, (quando Hitler anunciaria o recrutamento para um exército de trinta e seis divisões), era preciso lançar mão das emissões' para financiar as suas primeiras etapas. Indicava também, com certa alegria, que os fundos confiscados dos inimigos do Estado (em sua maioria judeus) e outros tomados das contas estrangeiras bloqueadas haviam ajudado a pagar as armas de Hitler. 'Dessa forma', disse, 'nossos armamentos são parcialmente financiados com os créditos de nossos inimigos'. Embora houvesse protestado a maior inocência, no seu julgamento de Nuremberg, contra as acusações de que participara na conspiração nazista para realizar a guerra de agressão, dizendo que fizera precisamente o contrário, o fato é que nenhuma pessoa foi tão responsável como Schacht, pela preparação econômica da Alemanha para a guerra que Hitler desencadeou em 1939". 


\section{Mais dinheiro, mais capital, mais trabalho}

Schacht saiu da prisão sem dinheiro e sem nenhuma propriedade. Teve que voltar a trabalhar. Primeiro escreveu um novo livro: preocupado com a grave situação econômica vivida pela Alemanha, no final da Segunda Guerra, publicou "Mais dinheiro, mais capital, mais trabalho", terminado em setembro de 1949. No prefácio, Schacht explicava que a função das idéias era sua aplicação prática; as teorias sem aplicação prática não teriam nenhuma utilidade na economia. Afirmava que a moeda era um dos pilares da vida econômica moderna, e que a elevação do nível de vida era impossível sem ela: "O dinheiro possibilita a formação do capital, a formação do capital possibilita o progresso material, o progresso material é a base de toda elevação cultural" (Schacht, 1950, p. 13).

Mostrava-se contrário à ocupação da Alemanha pelos aliados, que não estavam conseguindo resolver os problemas econômicos de seu país. Embora o Plano Marshall tivesse provido alimentos para o povo alemão, a administração aliada não tinha sido capaz de recuperar a destruída indústria alemã.

A Europa vivia o caos monetário após a guerra. Suas recomendações eram: fixação da taxa de câmbio entre as diversas moedas européias (ou seja, taxas fixas de câmbio), visando ao crescimento do comércio exterior; e a distribuição parcial do ouro acumulado pelos Estados Unidos aos demais países do mundo (para restabelecer a estabilidade monetária internacional). ${ }^{35}$

Era contra o sistema socialista, dando como exemplo o sucesso econômico alemão nos anos 1930. Já o comércio bilateral tinha sido uma imposição das necessidades, mas o ideal seria o comércio multilateral. Quanto à reestruturação industrial, era importante contar com capitais externos, pois a poupança interna das empresas era insuficiente, e uma emissão monetária poderia provocar inflação.

Schacht (1950) explicava que o dinheiro não era capital, mas podia ser transformado em capital quando investido na produção. Seguindo a Teoria Quantitativa da Moeda, Schacht aceitava que "o volume de dinheiro circulante deve guardar uma relação bem proporcional com o volume de bens" (Ibid., p.95). No entanto, o volume de dinheiro em circulação numa economia era variável, pois a produção de bens também era variável:

Um aumento na circulação monetária, simultâneo com o aumento da circulação de bens, de nenhum modo ocasiona fenômenos inflacionários (...) Constitui a finalidade de toda política monetária e bancária, desde o ponto de vista do Banco Emissor, manter o valor do dinheiro, em relação ao valor dos bens, o mais uniforme possível e sem grandes oscilações. Um aumento da circulação monetária que se

(35) Segundo Schacht (1950, p. 42-43), “(...) o intercâmbio de pagamentos com o exterior constitui um fator decisivo para a estabilidade. Enquanto os créditos e débitos monetários frente ao estrangeiro se equilibram, a moeda não está ameaçada". 
mantenha em consonância com o aumento das transações econômicas não é de nenhum modo inflacionário, e é indistinto que no transcurso de um desenvolvimento aproximadamente correlativo, um ou outro fator dê o impulso inicial. Em princípio todo crédito é inflacionário, porque produz um movimento de forças de capital maiores que as existentes (Schacht, 1950, p. 95-96).

Diante disso, Schacht acreditava que o impulso inicial dessa relação não pertencia apenas aos bens produzidos (quando aumenta a produção de bens aumenta a necessidade de dinheiro). Mas o contrário também era possível: um aumento na quantidade de dinheiro em circulação poderia elevar a quantidade de bens produzidos, sem efeitos inflacionários. Como exemplo, lembrou os Saques Mefo que financiaram as obras públicas na Alemanha e, entre 1933 e 1935, extinguiram o desemprego de 6,5 milhões de pessoas, sem criar inflação: "Não se produziu nenhum efeito inflacionário, porque o volume de bens cresceu rapidamente de forma tal, que ofereceu um equivalente ao incremento do volume monetário" (Ibid., p. 97). Conclui, então, que nem todo aumento de crédito ou dinheiro em circulação produz efeitos inflacionários: "Se a criação monetária desperta um repentino aumento de bens, então o aumento monetário se compensa com o aumento de bens" (Ibid., p. 98-99).

Em seguida a essa explicação teórica, Schacht expõe o seu plano para recuperar a economia alemã. O plano era o seguinte: criar no Bank for International Settlements (BIS) uma seção apenas para a Alemanha. Os Estados Unidos concederiam, via BIS, um crédito de US\$ 1 bilhão em ouro para a Alemanha. A Alemanha emitiria moeda em cima desse ouro, numa proporção igual ao estabelecido para os Estados Unidos na conferência de Bretton Woods (US\$ 35 por grama de ouro). Essa moeda teria o nome de "Taler". ${ }^{36}$ Seriam, então, concedidos créditos em taler às indústrias de exportação alemãs. A Alemanha não pagaria juros pelo empréstimo dos Estados Unidos; porém os tomadores alemães deveriam pagar juros dos empréstimos (3,3\% ao ano) ao banco central alemão, e a amortização média deveria ser de 30 anos. Dessa forma, a criação desse dinheiro para crédito se transformava em capital, e capital investido significava maior demanda por trabalho; daí o nome de seu livro.

Para Schacht, a emissão da nova moeda não causaria inflação, desde que fosse emitida no limite estabelecido acima: "Porém, é perfeitamente imaginável que não se produzirão fenômenos inflacionários, na forma de aumentos extraordinários de preços e outros similares, porque os Taler-ouro colocados em inversões novas produzirão imediatamente um forte incremento na transação de bens" (Schacht, 1950, p. 133). Para dar credibilidade ao taler, Schacht recomendava que o Federal Reserve (banco central dos Estados Unidos) deveria

(36) "Taler" era o nome de uma antiga moeda de prata que circulou pela primeira vez, na Alemanha, ainda no século XVI. 
aceitar a troca de taler por dólar em qualquer momento. O ouro emprestado à Alemanha ficaria depositado no próprio Fed.

Percebemos, tanto pelo seu novo plano como pela análise de suas memórias, que Schacht tinha uma grande vontade de voltar a trabalhar pelo seu país. Tinha vontade e um plano. No entanto, nunca mais seria chamado. Após escrever esse livro, Schacht atuou como consultor em vários países da Ásia. Terminou de escrever suas memórias em 1953, aos 76 anos. Nesse mesmo ano, abriu seu próprio banco, Schacht \& Co., encerrando suas atividades em 1963, em razão de sua aposentadoria. Morreu em Munique no dia 4 de junho de 1970, aos 93 anos, após um tombo no momento de se vestir para uma festa. Em sua autobiografia, resume seus maiores êxitos na condução da economia alemã:

Com exceção de algumas tarefas menores e secundárias, consegui intervir com êxito por três vezes na configuração das condições socioeconômicas. A primeira vez foi quando se tratava de afastar o perigo comunista, dando ao povo alemão novamente uma moeda estável. O problema não se resolvia simplesmente com a criação teórica de um Rentenmark ou "marco-centeio". A decisão aconteceu após uma luta de meses pela manutenção da estabilidade do Reichsmark e uma política de financiamento que manteve o valor do Reichsmark durante anos no mesmo nível. No começo dos anos 30, quando o desemprego atingiu o limite dos 7 milhões, tratava-se novamente de tirar o solo fértil para a ameaça do comunismo. Utilizando métodos financeiros racionais porém ousados, foi possível em menos de três anos dar salário e pão a todos os desempregados sem que a moeda fosse ameaçada. A situação financeira do Reich melhorava a olhos vistos de ano para ano. O terceiro êxito foi a recuperação de uma balança comercial equilibrada através da introdução de tratados comerciais e de compensação bilaterais com os países que suplementavam a economia alemã, abandonando a política praticada até então de tratamento preferencial de nação mais favorecida, que atendia aos interesses apenas dos países economicamente fortes (...) Entretanto, esses êxitos foram sombreados por acontecimentos históricos trágicos. Minha política monetária foi frustrada pelo endividamento desenfreado dos governos de Weimar e pela chantagem das reparações de nossos inimigos. Minha política comercial e de geração de empregos foi destruída pela loucura da guerra hitlerista (Schacht, 1999, p. 637-638).

\section{Considerações finais}

Na primeira metade do século XX, o nome do economista alemão Hjalmar Schacht foi mundialmente reconhecido por causa de seus bons resultados no combate à inflação e ao desemprego. Mediante uma ilusão monetária (o rentenmark), somada à fixação da taxa de câmbio e à equalização do déficit público, conseguiu estabilizar a moeda alemã em poucos dias e manter seu valor ao longo dos anos. Defrontado com o desemprego de 6,5 milhões de trabalhadores (cerca de $40 \%$ da força de trabalho) durante a Grande Depressão dos anos 1930, implementou um programa de obras públicas financiado por outra ilusão 
Miguel Couto

monetária (os Saques Mefo), que em menos de dois anos extinguiu o desemprego no país, sem causar um retorno da inflação.

Era um liberal, a favor do livre-comércio e da não-intervenção estatal na economia. No entanto, quando se defrontou com problemas práticos, abandonou suas convicções e adotou o comércio bilateral e a intervenção do Estado na economia.

Por causa de suas proezas no campo monetário, foi considerado um "bruxo" por alguns e um "mago das finanças" por outros. Sua autobiografia, lançada nos Estados Unidos, recebeu o sugestivo nome de "Confissões de um velho feiticeiro". Na verdade, Hjalmar Schacht conhecia o funcionamento do sistema capitalista; as relações existentes entre as variáveis econômicas. A economia em suas mãos era um mecanismo simples.

\section{Referências bibliográficas}

BRESCIANI-TURRONI, C. Economia da inflação: o fenômeno da hiperinflação alemã dos anos 20. Rio de Janeiro: Expressão e Cultura, 1989.

BUBHOLZ, H.; DASISTA, J. The German reparation issue: political and economic implications of the Versailles peace treaty. Kraków: Jagiellonian University, 2002.

DHM - DEUSTSCHES HISTORICHES MUSEUM. Weimar Republic und NS-Regime (1918-1939). Disponível em: <http://www.dhm.de/lemo/home.html>. Acesso em: 01 jul. 2005.

FANO, E. Los países capitalistas desde la guerra mundial hasta la crisis de 1929. In: TELÓ, M. (Org.). La crisis del capitalismo en los años 20: análisis económico e debate estratégico en la tercera internacional. México: Edições Pasado y Presente, 1981.

FEST, J. Hitler. Rio de Janeiro: Nova Fronteira, 1976.

FRANCO, G. O Plano Real e outros ensaios. Rio de Janeiro: Francisco Alves, 1995.

Schacht: aspectos econômicos. In: SCHACHT, H. Setenta e seis anos de minha vida. Rio de Janeiro: Editora 34, 1999.

GALBRAITH, J. K. Uma viagem pelo tempo econômico: um relato de primeira mão. São Paulo: Pioneira, 1994.

KEYNES, J. M. As conseqüências econômicas da paz. São Paulo: Ed. Universidade de Brasília, 2002.

REIS, R. R. Algumas considerações sobre a $2^{\mathrm{a}}$ Guerra Mundial e o direito internacional público. Âmbito Jurídico, mar. 2001. Disponível em: <http://www.ambitojuridico.com.br $>$. Acesso em: 08 maio 2005.

SCHACHT, H. The end of reparations. New Cork: J. Cape \& H. Smith, 1931.

1950.

Mas dinero, mas capital, mas trabajo. Buenos Aires: Selección Contable, 
Hjalmar Schacht e a economia alemã (1920-1950)

SCHACHT, H. The stabilization of the mark. New York: Arno Press, 1978.

Setenta e seis anos de minha vida. Rio de Janeiro: Editora 34, 1999.

SHIRER, W. L. Ascensão e queda do Terceiro Reich. v. I. Rio de Janeiro: Ed. Civilização Brasileira, 1964a.

Ascensão e queda do Terceiro Reich. v. II. Rio de Janeiro: Ed. Civilização Brasileira, 1964b.

VISCONTI, C. R. O contexto econômico e um contexto de alta inflação: um estudo da hiperinflação alemã. Dissertação (Mestrado)-Departamento de Economia, PUC, Rio de Janeiro, 1987.

WEBB, S. B. Hyperinflation and stabilization in Weimar Germany. New York: Oxford University Press, 1989.

ZINI JÚNIOR, A. A. Hiperinflação, credibilidade e estabilidade: um ensaio de interpretação de história monetária. In: ENCONTRO NACIONAL DE ECONOMIA, 21, Belo Horizonte, 1993. Anais... Belo Horizonte: Anpec, 1993. 